\title{
COMPARATIVE EFFECTS OF GARLIC (ALLIUM SATIVUM) BULB AND BULB COAT POWDER ON MAIZE WEEVILS (SITOPHILUS ZEAMAIS)
}

\author{
Ishaya M. ${ }^{1}$, John W.C. ${ }^{1 *}$, Oke $0 .{ }^{1}$, Chomini M.S. ${ }^{2}$, Oladejo A.O. ${ }^{1}$, Ihum T.A. ${ }^{3}$, \\ Olorundare 0.O. ${ }^{1}$, Ukanyirioha C.J. ${ }^{2}$, Ayorinde J.O. ${ }^{1}$, Sikiru G.K. ${ }^{1}$ \\ ${ }^{1}$ Department of Pest Management Technology, Federal College of Forestry Jos, Nigeria \\ ${ }^{2}$ Department of Forestry Technology, Federal College of Forestry Jos, Nigeria \\ ${ }^{3}$ Nigeria Stored Products Research Institute, Ilorin, Nigeria \\ ${ }^{*}$ E-mail: jowaltee@gmail.com
}

\begin{abstract}
In Nigeria, maize serves as a staple food and a good source of carbohydrates, protein, vitamin B and minerals, hence, the need to protect it against Sitophilus zeamais. This study was conducted to determine the phytochemical properties and insecticidal potentials of Allium sativum bulb and bulb coat powders against Sitophilus zeamais. Allium sativum bulb and bulb coat were collected, dried, and pulverized into fine powder. A 0, 2.0, 3.0, 4.0, and $5.0 \mathrm{~g}$ of the plant powder were used. Each treatment had 16 newly emerged maize weevils. The weevils were mixed with $250 \mathrm{~g}$ un-infested maize grains in $500 \mathrm{ml}$ bottles and kept at room temperature. Mortality was observed for 7 days at 24 hours intervals post treatment. The experiment was laid out in a Completely Randomized Design and treatments were replicated three times. Data obtained were analyzed using a one-way ANOVA and means were separated using Duncan multiple Range test. The results revealed that both parts showed significant percentage mortality $(P \leq 0.05)$. The results showed that as the dosage of the bulb powder increased from 2 - $5 \mathrm{~g}$, percentage mortality increased from 16-32.8\%. For bulb coat powder, percentage mortality increased from 16.5-32.1\%. The control showed mortality of 3.0 and $2.8 \%$ for the bulb and bulb coat powders, which were significantly different $(P<0.05)$ from the mortality in treated maize. The most effective dosage for both powders is $5 \mathrm{~g}$. Based on the results obtained, Garlic bulb and garlic bulb coat could be used in the management of Sitophilus zeamais infestation.
\end{abstract}

\section{KEY WORDS}

Garlic bulb, garlic bulb coat, Sitophilus zeamais, mortality, dosages, phytochemical.

Global food security has been threatened by the advent of the corona virus as farmers have the challenges of accessing their farms because of the lockdown imposed globally. The lockdown also made movement of agricultural machines, agrochemicals, fertilizer, and other input nearly impossible. The trade restrictions on major commodities like wheat and rice imposed by food producing countries like Kazakhstan, Russia, and Romania Thailand, Cambodia, and India is of a great concern (Zurayk, 2020). Maize (Zea mays) is an important cereal grain widely cultivated and consumed globally. In Africa it serves as a staple food with great nutritional value, being a good source of carbohydrates, protein, vitamin B and minerals in the major producing areas. It is ranked third next to wheat and rice (Bashir and Shafie, 2013). Many small holder farmers in developing countries live in remote and inaccessible areas with poor road networks making it difficult for them to take their produce to the markets.

The farmers therefore require storing their grains for a period of up to 6-8 months after harvest and Sitophilus zeamais have become a menace during this period as most of the poor farmers especially in Africa still use the Open Pollinated Maize variety (OPMVs) which is not resistant to the weevils (Pingali and Pandey, 2001). The attack by this weevil usually starts in the field when the moisture content of the grains is between $18-20 \%$. Infestations in store result from the transfer of infested grain into store or from the pest flying into storage facilities, probably attracted by the odour of the stored grain. Ogunsina et al. (2011) and Radha (2014) revealed that heavy infestation due to this pest in storage may cause weight 
losses of about 30-40\%. According to Yohannes et al. (2014), an estimated global annual loss due to the weevil's activity in the field and in store was valued at more than $\$ 100$ billion.

Farmers have largely depended on the use of synthetic insecticides as insect pest control measures against Sitophilus zeamais. These chemicals however have some limitations such as development of resistance in the pest organisms, hazardous effect on the environment, high persistence, high toxicity, residues accumulation in food and feed, as well as negative effects on non-target organisms (Dhuyo and Ahmed, 2007). In view of these problems caused using synthetic chemicals, there is growing need for alternative methods of pest control that would minimize these damages, such as substances from plants (Wan et al., 1996).

\section{MATERIALS AND METHODS OF RESEARCH}

The Study Area. The experiment was carried out at the Entomology Laboratory at Federal college of forestry Jos, located in Jos-North of Plateau State, Nigeria. The area is located on latitude $9^{\circ} 56^{\prime} \mathrm{N} 8^{\circ} 53^{\prime} \mathrm{E}$ with average annual rainfall of $14600-14800 \mathrm{~mm}$ and average annual temperature range of $10-32^{\circ} \mathrm{C}$ (Akin, 2002).

Sample collection. The maize and garlic used in this experiment were procured from a local market in Jos north Local Government Area of Plateau State. Highly infested maize grains were also purchased from the same market to obtain a stock culture of the Sitophilus zeamais. The uninfested maize grains were sieved to remove broken seeds and kept in freezer at $4^{0} \mathrm{C}$ for 2 weeks to kill potential eggs that might be on the grains.

Culturing of the maize weevils. One gram of infested maize grains containing the adults, larvae and eggs were sieved to remove the adults and kept in a plastic bowl covered with a muslin cloth. The newly emerged adults of between 24-72 hours were used for the experiment.

Preparation of plant materials. Garlic cloves obtained from the market were separated into bulbs and bulb coat. The garlic bulb coat was then collected and air dried in the laboratory at room temperature for a period of 21 days. The separated garlic bulbs were subsequently chopped into tiny pieces using sterilized knife and air-dried on a platform in the laboratory at room temperature for a period of 21 days until they were dried enough to yield powder. The dried garlic bulbs and garlic bulb coat were pulverized into powder using pestle and mortar. The powdered garlic bulb and garlic bulb coat $(50 \mathrm{~g})$ were then labeled and stored in two separate bottles in a cool dry laboratory cabinet.

Application of treatment. Uninfested maize grains of $250 \mathrm{~g}$ were put into a $500 \mathrm{ml}$ bottles and varying dosages of the garlic bulb and garlic bulb coat powder were added at 2.0, 3.0, 4.0 and $5.0 \mathrm{~g}$ and the controls to which nothing were added. The maize grains and the powders were thoroughly mixed and allowed to stand for 24 hours before the introduction of the weevils. To each of the bottles, 16 newly emerged adult maize weevils in the ratio of 1:1 were introduced and data on mortality of the weevils were collected at 24 hours intervals for 7 days.

Percentage mortality (Chomini et al., 2005) was then calculated as:

$$
\% \text { Mortality }=\frac{\text { Number of Dead Weevils }}{\text { Total Number of Weevils }} \times 100
$$

\section{RESULTS AND DISCUSSION}

The results of phytochemical analysis suggested that several phytochemicals are present in Allium sativum bulb and bulb coat powder. According to Ibrahim et al. (2010), these phytochemicals give plants their colours, flavours, smell and are part of a plant's natural defense system; protecting them against herbivorous insects and vertebrates, fungi, pathogens, and parasites. The phytochemicals Saponins, flavonoid, tannin, carbohydrate, steroid, and terpenoid were present in Allium sativa powders according to this study. The phytochemical contents of the powder of $A$. sativum revealed that the Alkaloids and 
carbohydrate was found to be the most abundant phytochemicals followed by tannin, saponins and flavonoids (Table 1). Alkaloids are the most important group of natural substances playing an important role in insecticidal properties of the plant (Rattan, 2010) and Flavonoids play an important role in the protection of plants against plant feeding insects' and herbivores and could be useful in a pest-management strategy (Acheuk and DoumandjiMitiche, 2013).

Table 1 - Phytochemical Constituents of the Bulb and Bulb Coat Powders of Garlic

\begin{tabular}{lll}
\hline Constituents & Bulb Powder & Bulb Coat Powder \\
\hline Alkaloids & +++ & ++ \\
Tannins & ++ & - \\
Flavonoids & + & + \\
Saponins & ++ & +++ \\
Carbohydrates & +++ & + \\
Steroids & + & + \\
Anthraquinones & + & - \\
Terpenoid & + & \\
\hline
\end{tabular}

The result revealed that both garlic bulb and garlic bulb coat had high mortality at $5 \mathrm{~g}$ for 24 and 48 hours post treatment. The bulb powder had the highest mortality of $37.8 \%$ and $31.0 \%$ ( 5 and $4 \mathrm{~g}$ ) with least mortality of $17.8 \%$ and $17.2 \%$ ( 3 and $2 \mathrm{~g}$ ); while the bulb coat powder had highest mortality of $36.4 \%$ and $36.1(5$ and $4 \mathrm{~g}$ ) with least mortality of $13.6 \%$ and $16.7 \%$ ( 3 and $2 \mathrm{~g}$ ). For 72 and 96 hours post treatment, the garlic bulb powder had a high mortality of $36.1 \%$ and $33.3 \%$ at $(5$ and $4 \mathrm{~g}$ ) and least mortality of $15.8 \%$ and $14.3 \%$ ( 3 and $2 \mathrm{~g}$ ). The mortality caused by the garlic bulb coat powder at 72 and 96 hours post treatments were $26.3 \%$ and $28.6 \%$ for 5 and $4 \mathrm{~g}$ respectively. The decline in mortality observed after 120 hours of treatment may not be unconnected with the fact that the potency of most chemicals decrease with increasing time and the mortality observed in the control may probably be due to environmental factors.

Table 2 shows the effects of garlic parts powder on mortality of $S$. zeamais. The result shows that both the bulb and the bulb coat powders had caused mortality in the weevils. This result corroborates with Ibrahim and Garba (2011) who found garlic powder to be effective in the control of maize weevil. Zhao et al. (2013) also observed that the essential oil of $A$. sativum possessed contact toxicity against overwintering Cacopsylla chinensis (Hemiptera:Psyllidae). The compounds diallyl trisulfide and diallyl disulfide which are the two main constituents of garlic exhibited strong acute toxicity against the overwintering $C$. Chinensis. Furthermore Feng-Lian et al. (2011) reported that garlic essential oil diallyl disulfide and diallyl trisulfide inhibited the development of grain moth Sitotroga cerealella (Lepidoptera:Gelechidae). Additionally, Ofuya et al. (2010) confirmed that fumigation of pods with crushed bulbs of $A$. sativum and Allium cepa, showed a toxic effect to Callosobruchus maculatus (Coleoptera: Bruchidae). The mortality of the weevils in this study could be as a result of the allicin present in the garlic which is the sulphur-base compound found in the alkaloids of the garlic. This agrees with the work of Shinsuke et al. (2006) who reported that when garlic cloves are chopped, chewed or crushed, the enzymes in the cloves triggers the breakdown of several sulphur-containing compounds stored in the cell fluids (cytosol) and resultant compounds such as allicin, ajoene, diallyl polysulfides, diallyldisulfide and diallyltrisulfide are responsible for the sharp or hot taste and strong smell of garlic that serves as insecticide and deters worm, birds and other animals from the plant. The finding is also in agreement with Adedire and Ajayi (1996) who suggested that the garlic's pungency which is as a result of the sulphur-base compounds contributes to its toxicity in weevils by disrupting regular respiratory events and subsequently lead to their death. The finding further agrees with Ibrahim et al. (2010) and Shuford (2005) who reported that alkaloid is the most abundant phytochemical in garlic and that it contains the sulphur-base compounds allicin, ajoene, diallyl polysulfides. Sovova (2004) also confirms that allicin, along with its derivatives; diallyldisulfide and diallyltrisulfide are major contributors to the characteristic odour of garlic that deters insects and other animals from the plant. Garlic essential oil and its constituents, 
diallyl sulfide and diallyl disulfide have shown to be highly toxic to $S$. zeamais and $T$. castaneum (Huang et al., 2000) at different developmental stages.

Table 2 - Effect of Garlic Parts (Bulb Powder and Bulb Coat Powder) on Maize Weevil

\begin{tabular}{lllllll}
\hline Plant powders & Conc. & $24 \mathrm{~h}$ & $48 \mathrm{~h}$ & $72 \mathrm{~h}$ & $96 \mathrm{~h}$ & $120 \mathrm{~h}$ \\
\hline Garlic Bulb & $2.0 \mathrm{~g}$ & $0.3 \pm 2.67^{\mathrm{c}}$ & $0.3 \pm 1.67^{\mathrm{b}}$ & $0.2 \pm 1.00^{\mathrm{b}}$ & $0.3 \pm 1.00^{\mathrm{cd}}$ & $0.3 \pm 1.00^{\mathrm{a}}$ \\
Powder & $3.0 \mathrm{~g}$ & $0.3 \pm 3.00^{\mathrm{bc}}$ & $0.3 \pm 2.33^{\mathrm{ab}}$ & $0.2 \pm 1.67^{\mathrm{ab}}$ & $0.3 \pm 1.33^{\mathrm{bc}}$ & $0.3 \pm 0.33^{\mathrm{a}}$ \\
& $4.0 \mathrm{~g}$ & $0.3 \pm 3.67^{\mathrm{b}}$ & $0.3 \pm 2.67^{\mathrm{a}}$ & $0.2 \pm 1.67^{\mathrm{ab}}$ & $0.3 \pm 2.00^{\mathrm{ab}}$ & $0.3 \pm 0.33^{\mathrm{a}}$ \\
& $5.0 \mathrm{~g}$ & $0.3 \pm 5.67^{\mathrm{a}}$ & $0.3 \pm 3.00^{\mathrm{a}}$ & $0.2 \pm 2.00^{\mathrm{a}}$ & $0.3 \pm 2.33^{\mathrm{a}}$ & $0.3 \pm 0.00^{\mathrm{a}}$ \\
Garlic Bulb & $\mathrm{Ctrl}$ & $0.3 \pm 0.00^{\mathrm{d}}$ & $0.3 \pm 0.00^{\mathrm{c}}$ & $0.2 \pm 0.00^{\mathrm{c}}$ & $0.3 \pm 0.33^{\mathrm{d}}$ & $0.3 \pm 1.00^{\mathrm{a}}$ \\
Coat Powder & $2.0 \mathrm{~g}$ & $0.4 \pm 2.00^{\mathrm{b}}$ & $0.2 \pm 2.00^{\mathrm{c}}$ & $0.3 \pm 1.33^{\mathrm{c}}$ & $0.4 \pm 0.67^{\mathrm{a}}$ & $0.2 \pm 0.00^{\mathrm{a}}$ \\
& $3.0 \mathrm{~g}$ & $0.4 \pm 2.67^{\mathrm{b}}$ & $0.2 \pm 2.00^{\mathrm{c}}$ & $0.3 \pm 1.67^{\mathrm{a}}$ & $0.4 \pm 0.67^{\mathrm{a}}$ & $0.2 \pm 0.00^{\mathrm{a}}$ \\
& $4.0 \mathrm{~g}$ & $0.4 \pm 4.33^{\mathrm{a}}$ & $0.2 \pm 3.67^{\mathrm{b}}$ & $0.3 \pm 1.67^{\mathrm{a}}$ & $0.4 \pm 0.67^{\mathrm{a}}$ & $0.2 \pm 0.33^{\mathrm{a}}$ \\
& $5.0 \mathrm{~g}$ & $0.4 \pm 5.33^{\mathrm{a}}$ & $0.2 \pm 4.33^{\mathrm{c}}$ & $0.3 \pm 1.67^{\mathrm{a}}$ & $0.4 \pm 0.33^{\mathrm{a}}$ & $0.2 \pm 0.00^{\mathrm{a}}$ \\
& Ctrl & $0.4 \pm 0.33^{\mathrm{c}}$ & $0.2 \pm 0.00^{\mathrm{d}}$ & $0.3 \pm 0.00^{\mathrm{b}}$ & $0.4 \pm 0.00^{\mathrm{a}}$ & $0.2 \pm 0.67^{\mathrm{a}}$ \\
\hline
\end{tabular}

Each value is a mean of \pm standard error of three replicates. Mean followed by the same superscripts in a column are not significantly different from each other.

The result of the phytochemical analysis also revealed that tannins and saponins are the second most abundant phytochemicals available in the garlic bulb powder. This could also be the reason for the mortality of the weevils as tannins are said to deter many insects' pest from plants that have high amount of tannin in them which may have led to starvation in the insects since they were in an enclosure. This is in line with Huang et al. (2018) who reported that tannins, as secondary metabolites of plants, contribute to their chemical defense, protecting them from possible attacks by pathogens, insects, herbivores, opportunist organisms as well as adverse abiotic conditions. Also, tannins, when ingested by insects tend to interfere with their biochemical activities such as enzymatic activities which may lead to their subsequent death. The mortality observed in the weevils could also be attributed to the presence of tannins which serve as cardiac glycosides that have repellent and deterrent effect on the weevils thereby preventing them from attacking the maize grains and hence starving them to death (Dawit and Bekele, 2010; kalia, 2011).

\section{CONCLUSION}

The result of this experiment revealed that amongst the two plant parts, the bulb powder performed better than the bulb coat powder and can be used because of its insecticidal potential. It also showed that as dosages increased, mortality of the weevils increased; on the other hand, as the time of exposure increased, the potency of the plant parts decreased causing decline in the mortality of the weevils. Since the mortality of the weevils was directly proportional to increase in the dosage, there is need to further increase the dosages for better result. There is also need to add the powder of the garlic parts periodically to stored grain as the potency decreases with increasing time of exposure and finally, small holder farmers should be involved in growing the garlic to reduce cost of procurement.

\section{REFERENCES}

1. Acheuk, F., Doumandji-Mitiche, B. (2013). Insecticidal activity of alkaloids extract of Pergularia tomentosa (Asclepiadaceae) against fifth instar larvae of Locusta migratoria cinerascens (Fabricius 1781) (Orthoptera: Acrididae). International Journal of Science and Advanced Technology, 3(6), 8-13.

2. Adedire, C. O. and Ajayi, T. S. (1996). Assessment of the Insecticidal Properties of Some Plant Extracts as Grain Protectants against the Maize weevil. Sitophiliis zeamais Molnchulsky. Nigerian Journal of Entomology, 13: 93-10.

3. Akin, O. (2002). 'The Geographical Location of Different Towns in Nigeria', in Senior Secondary Geography Book3, $3^{\text {rd }}$ Edition Published 2004. pp64. 
4. Bashir. E.M. and Shafie, H.A.F. (2013). Insecticidal and antifeedant Efficacy of Jatropha oil extract against the Desert Locust, Schistocerea gregaria (forskal) (Orthopthera: Acrididae). Agricultural and Biology Journal of Northern Nigeria 4(3):260-267.

5. Chomini, M. S., Akalusi, M. E., Okoiyele, L. O., Nwakuwonhue, K. N., and Karma, L E (2006): Insecticidal Effects of Leaf, Stem Bark and Seed Kernel Powdered Extracts of Neem (Azadirachta indica A. Juss) against Maize Weevil (Sitophilus zeamais Motchulsky). Nigerian Journal of Botany 19(2)348-352.

6. Dawit, K.Z. and Bekele, J. (2010). Evaluation of orange peels (Citrus sinensis L.) as source of repellent, toxicant and protectant against Zebrotes subfasiatus (Coleoptera: bruchidae) C.N.C S. Makelle University, 2 (1): 61-75.

7. Dhuyo, A. R. et al (2007): Evaluation of the Fungus Beavaria bassiana (Bals.) Infectivity to the Larger Grain Borer Prostephanus truncatus (Horn), Pak. Entomol., 29: 77-82.

8. Feng-Lian Y. et al (2011). Insecticidal activities of garlic substances against adults of grain moth, Sitotroga cerealella (Lepidoptera: Gelechidae) Insect Sci. 19(2): 205-212.

9. Huang, Y., Lam, S. L., \& Ho, S. H. (2000). Bioactivities of essential oils from Elletaria cardamomum (L.) Maton. to Sitophilus zeamais Motschulsky and Tribolium castaneum (Herbst). Journal of Stored Products Research, 36, 107-117.

10. Huang, Q. et al (2018). Potential and challenges of tannins as an alternative to in-feed antibiotics for farm animal production. Animal Nutrition, 4:137-150.

11. Ibrahim, N.D. \& S. Garba (2011). Use of garlic powder in the control of maize weevil. Proceeding of the 45 Annual conference of Agric. Soc. Nig. pp: 177-181.

12. Ibrahim, T. A.; Ibo, Dada; A., Adejare R. (2010). Comparative phytochemical properties of crude ethanolic extracts and physicochemical characteristics of essential oils of myristical fragrans (nutmeg) seeds and zingiber officinale (ginger) roots. Electronic Journal of Environmental, Agricultural \& Food Chemistry. 9(6): 1110-1116.

13. Kalia Grade 8 (2011). Plant extracts as natural insecticides. Part of the Young Naturalist Awards Curriculum Collection. Young Naturalist awards collection New York TNA.

14. Ofuya, T.I. et al (2010). Fumigant toxicity of crushed bulbs of two Allium to Callosobruchus malulatus (Fabricius) Species. Chilean J. Agric. Res. 70 (3):510- 514.

15. Ogunsina, O.O., M.O. Oladimeji and Lajide, L. (2011). Insecticidal action of hexane extracts of three plants against bean weevil, Callosobruchus maculatus (F.) and maize weevil, Sitophilus zeamais motsch. Journal Ecology Natural Environment 3: 23-28.

16. Pingali, P.L. \& Pandey, S. (2001) Meeting world maize needs Technology opportunities and priorities for the public sector. In: Pingali PL (Ed.), CIMMYT 1999-2000, World maize facts trends CIMMYT, Mexico, USA, pp. 337-345.

17. Radha, R., (2014). Toxicity of three plant extracts against bean weevil, Callosobruchus maculatus (F.) and maize weevil, Sitophilus zeamais motsch. International Journnal Curriculum of Resources. 6: 6105-6109.

18. Rattan, R. S. (2010). Mechanism of action of insecticidal secondary metabolites of plant origin. Crop Protection, 29, 913-920.

19. Shinsuke, T. et al (2006): Model Studies on Precursor System Generating Blue Pigment in Onion and Garlic. Journal of Agriculture and Food Chemistry, 54 (3): 848-852.

20. Shuford J. A., Steckelberg, J.M., Patel, R. (2005). Effects of Fresh Garlic Extract on Candida alblcans Biofilms. Antimicrob. Agents Chemother, 49 (1):473.

21. Wan, M. T., R. G. Watts, M. B. Isman and R. Strub (1996): Evaluation of the Acute Toxicity to Juvenile Pacific Northwest Salmon of Azadirachtin, Neem Extract, and Neem Products. Bull. Environ. Contam.Toxicol, 56: 432-439.

22. Yohannes, A. et al (2014). Evaluation of certain plant leaf powders and aqueous extracts against maize weevil, Sitophilus zeamais Motsch. (Coleoptera: Curculionidae). Asian Journal Agricultural Science 6: 83-88.

23. Zhao, N.N. et al (2013). Evaluation of acute toxicity of essential of garlic (Allium Sativum) and its selected major constituents against over wintering Cacopsylla chinensis (Hemiptera: Psyllidae). Journal of Economic Entomology, 106 (3): 1349-1354.

24. Zurayk, R. (2020). Pandemic and food security: A view from the Global South. Journal of agriculture, Food Systems, and Community Development, 9 (3):17-21. 